\title{
Development of Local Membership based Student Worksheets to Improve Process Skills on Life Creations Adaptation Materials
}

\author{
Rita Rahmaniati \\ Lecturer in Elementary Teacher Education, Universitas Muhammadiyah Palangkaraya, \\ RTA Milono St. Km. 1,5, Palangka Raya, Indonesia \\ \{rahmaniatirita@gmail.com\}
}

\begin{abstract}
This study aims to produce student worksheets based on local wisdom to improve standard process skills and know the improvement of students' science process skills. The method used in this research is the development method with ADDIE model. The results of the development of student worksheets based on local wisdom through the process of expert test results were declared to be suitable as teaching materials. The effectiveness test showed that the results of the science process test showed an increase from an average pretest and posttest. Student worksheets based on local wisdom can improve student learning outcomes and science process skills.
\end{abstract}

Keywords: LKS Based on local Skills, Process Skills

\section{Introuction}

Learning so far has implemented the 2013 curriculum using teaching materials which include LKS (Student Worksheets) that have used the Scientific approach (science process). However, teachers and students still have difficulty applying it in learning and the science process is still low. The low science process of students affects students' ability to think critically, creatively and innovatively, students are easily influenced by other people's opinions, avoid problems, solve problems without thinking deeply, have not been able to solve their own problems, and feel inferior when they have to be different from others . If this condition is allowed to drag on and is not corrected immediately, it will also have an impact on student learning outcomes as a whole. Therefore it is necessary to develop learning tools, especially Student Worksheets (LKS) (Desianti et al., 2015).

LKS that are in accordance with the demands of the science curriculum, namely LKS which refers to the process skills approach through investigation which is able to foster the ability to think, work and have a scientific attitude and communicate it as an important aspect of life skills, so that it places more emphasis on providing direct learning experiences. The development of local active-based worksheets will produce worksheets that are easy to apply in learning because they use local practicum materials and are expected to improve students' science process skills, so that learning is more meaningful (Anggraini et al., 2016). 
Development of worksheets based on local practicum materials to improve the science process skills of elementary school students, so that they are able to face all challenges in real life. Worksheets based on local practicum materials are designed according to the needs of elementary school students and practice materials using real objects and partly assisted by image media to make it easier for students to learn while familiarizing students with local practicum materials. LKS is a student worksheet which is a stimulus or teacher guidance in learning that will be presented in writing so that in writing it is necessary to pay attention to the criteria for graphic media as visual media material to attract student attention. Farid 2010 stated that the contents of the LKS message must pay attention to the elements of good and correct writing and the most important thing is the selection of questions as an efficient and effective stimulus.

The use of local active-based worksheets is an alternative for teachers to improve the science process skills of elementary school students. Because by using LKS based on local activism, students are guided in detail on the steps of the scientific process. In addition, LKS based on local activism can be used to find students' ideas, and also provide information for teachers to find out how students think, trigger discussion activities, motivate students to explore their knowledge and trigger students to carry out investigations.Science process skills are all the skills needed to acquire, develop, and apply science concepts, laws, and theories, in the form of mental skills, physical skills and social skills. Science process skills consist of basic skills and integrated skills. Basic skills include six skills, namely observing, classifying, predicting, measuring, concluding and communicating. Meanwhile, integrated skills consist of identifying variables, tabulating data, presenting data in graphical form, describing relationships between variables, collecting and processing data, analyzing research, developing hypotheses, defining variables operationally, designing research and carrying out experiments (Lepiyanto, 2014). ).

Science process skills as an approach to learning are very important because they foster experiences other than the learning process. Given the increasing number of schools that have biological laboratories, it is necessary to increase the effectiveness of learning, especially the achievement of cognitive learning outcomes supported by good skills and attitudes and behavior. Therefore, teachers should gradually start moving to assess learning outcomes in terms of skills and attitudes (Acesta, 2014).

Table 1. Indicators of Science Process Skills According to Warianto (2011)

\begin{tabular}{ll}
\hline Science Process Skills & \\
\hline Observation & 1. Using as many senses as possible \\
Classification & 2. Gather or use relevant facts \\
& 1. Record each observation separately \\
& 2. Look for differences and similarities \\
& 3. Contrast the features \\
& 4. Comparing \\
& 5. Looking for the basis of grouping or classification \\
Interpretation & 6. Linking observations \\
& 1. Linking observations \\
Prediction & 2. Finding patterns in a series of observations \\
Asking Question & 1. Summing up \\
& 2. Suging the observed patterns \\
& 1. Ask what, how, and why \\
& 2. Ask for an explanation \\
\hline
\end{tabular}




\begin{tabular}{|c|c|}
\hline Science Process Skills & $\begin{array}{l}\text { Indicators } \\
\end{array}$ \\
\hline Hypothesizing & $\begin{array}{l}\text { 1. Knowing that there is more than one possible explanation for an event } \\
\text { 2. Recognizing that an explanation needs to be verified in order to obtain } \\
\text { more evidence }\end{array}$ \\
\hline Planning Experiments & $\begin{array}{l}\text { 1. Determine the tools / materials / sources to be used } \\
\text { 2. Determine the variable or determining factors. } \\
\text { 3. Determine what will be measured, observed, recorded } \\
3 \text { 4. Determine what will be carried out in the form of work steps }\end{array}$ \\
\hline Using tools / materials & $\begin{array}{l}\text { 1. Using tools and materials } \\
\text { 2. Knowing the reasons why using the tools / materials } \\
\text { 3. Know how to use tools and materials }\end{array}$ \\
\hline Apply the concept & $\begin{array}{l}\text { 1. Using concepts that have been learned in new situations } \\
\text { 2. Using concepts in new experiences to explain what is going on }\end{array}$ \\
\hline Communicate & $\begin{array}{l}\text { 1. Describe empirical data from experiments or observations with graphs, } \\
\text { tables and diagrams } \\
\text { 2. Compile and submit reports systematically } \\
\text { 3. Describe the results of the experiment or research } \\
\text { 4. Read charts or chart tables } \\
\text { 5. Discuss the results of activities of a problem or an event } \\
\text { 6. Change the form of presentation }\end{array}$ \\
\hline
\end{tabular}

\section{Research Methods}

The stages in this research include: 1) Needs analysis, 2) Development of worksheets models based on local practicum materials, and 3) Implementation of worksheets based on local practicum materials to test the effectiveness of the products developed. The research location is planned at SDN Palangkaraya City. The development model used by researchers is the ADDIE model consisting of 5 phases or main stages, namely Analysis, Design, Development, Implementation, and Evaluation. Data Analysis The data analysis techniques in this study were as follows 1) Data about the results of interviews, needs analysis questionnaires, student response questionnaires and expert validation results were analyzed descriptively in percentage 2) Data on science process skills improvement were analyzed using the N-Gain formula.

\section{Research Results and Discussion}

\subsection{The Results of the Development of Worksheets Based on Local Practicum Materials}

The development of worksheets based on local practicum materials after going through stages and exp. Based on the results of research and development that has been done, data obtained include. The results of the needs analysis, the results of validation by experts, the feasibility of the model, the effectiveness of the model (cognitive learning outcomes, the results of improving student process skills.

\section{a) Needs Analysis Results}

Based on the results of the needs analysis and from the collected initial assignments, it was finally obtained that the student worksheet model framework would be developed. So far, the 
teacher has taught using student worksheets, but it is still not in accordance with the needs of students. An overview of student worksheets that have been implemented so far can be seen in table 2 below:

Table 2. Student worksheets have been used by teachers and students so far

\begin{tabular}{ll}
\hline No & No pre-development student worksheets \\
\hline 1. & Do not have work procedures that are easy for students to implement \\
2. & There are no scientific method steps \\
3. & The image is less attractive \\
4. & The language is less applicable to students \\
5. & The materials used are not recognized by students \\
6. & Questions in student worksheets have not been able to explore students' knowledge \\
7. & Students' ability to solve problems is still lacking \\
\hline
\end{tabular}

Based on table 2 above, there are some deficiencies in student worksheets that teachers and students usually use in their daily learning. Field surveys were also conducted to obtain a real picture of elementary school children in the city of Palangkaraya. The results of the field survey were obtained through questionnaires and interviews given to students.

\section{b) Validation Results by Experts}

The student worksheet product underwent a revision after an assessment of the quality of the prototype by an expert who had competence not only in the field of material / content but also in the fields of language and media. The results of validation by experts generally provide an assessment of the sufficient category $(2,8)$. The expert's assessment is the basis for the revision. After getting input from experts, the researcher then made improvements as suggested. Furthermore, the corrected student worksheet is re-validated by the expert. The results of validation by experts generally provide an assessment from the good to very good category until the average is good $(3,8)$. The purpose of further validation of the prototype is to obtain student worksheets that have been recommended and have valid criteria.

\section{c) Product Trials}

The results of product trials and usage trials showed that the LKS based on local practicum materials had good attractiveness criteria with a score of 3.00, good convenience with a score of 3.38 , the criteria for usefulness were very good with a category of score of 3.85 .

\section{d) Product Development Feasibility}

The appropriateness of the student worksheets developed through field tests in the implementation class. Achievement of student learning outcomes in the cognitive realm is obtained through prestest and posttest. Results Based on the results of the calculation for the total score of student learning outcomes in the implementation class 1, the average pretest was 42.50 and posttest 62.50 . The difference in the average score between pretest and posttest was 29.65 and $\mathrm{N}$ gain was 0.41 in the moderate category. The results of the feasibility test form the basis for testing the effectiveness of student worksheets in large-scale classes.

The development of worksheets based on local practicum materials after going through stages and expert validation and product testing, a proper worksheet is produced. The contents of the worksheets are adjusted to the needs and characteristics of elementary school students 
in Palangkaraya city who train students to be skilled in doing science process skills. The materials for the investigation activities are local practicum materials used are practical materials that can be easily obtained in Central Kalimantan, especially in the city of Palangkaraya using contextual examples, for example Kelakai plants, Semar bags, Masisin fruit plants, and Dayak onions and animal image media endemic to Central Kalimantan such as the peacock, orang-utan and tingang bird.

\subsection{Increasing Students' Science Process Skills}

Effective student worksheets can be identified through trials in larger classes, involving 2 classes (implementation class 1 and implementation class 2). The results of the student process skills test showed that the results of the science process test showed an increase from the average pretest 44.4 to an average of 60.4 in the post-test, $\mathrm{N}$ gain was 0.364 in the medium category in the Implementation 1 class and in the implementation class 2 the results of the science process test showed an increase from the pretest average of 59.75 to an average of 89.5 in the posttest, $\mathrm{N}$ gain is 0.82 in the high category in the Implementation class 2 . An increase in the results of this process skills test is in line with the research of Sugianto (2013) shows that Science process skills are suitable for use in science learning on the theme of photosynthesis and are effective in improving students' scientific work. Research by Susilo, Abas \& Atun, Sri. (2017) show that science worksheets with the Guided Inquiry approach can improve science process skills, critical thinking skills, and cognitive learning outcomes of seventh grade junior high school students.

\subsection{Student Responses to Learning Using LKS Based On Local Practicum Materials}

Based on the results of the student response questionnaire, it can be seen from the following diagram:

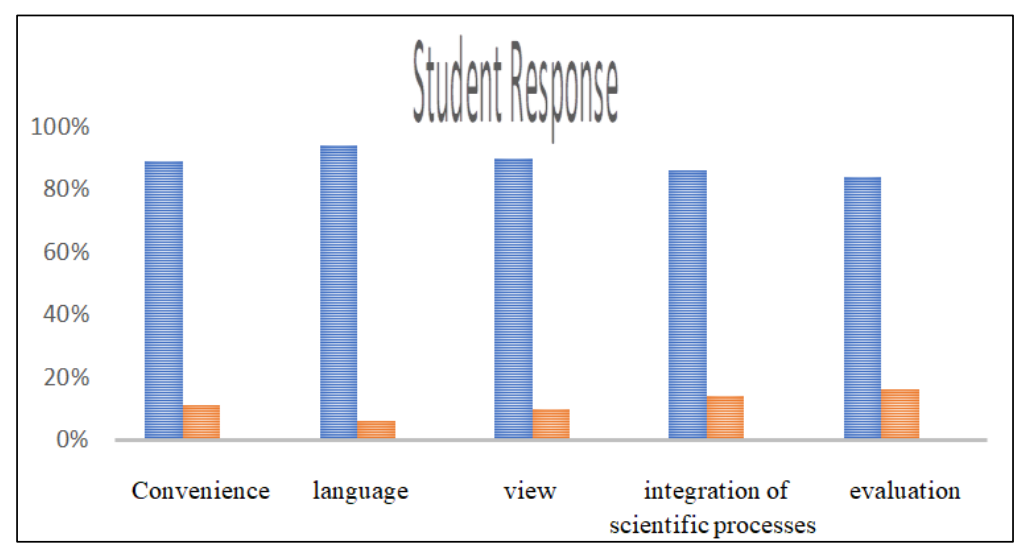

Fig. 1. Student Response Diagram

According to students, learning using worksheets based on local practicum materials makes it easier for them to understand the material, use language and easy to apply it in everyday life. Most students also stated that the display of worksheets based on local practicum materials was attractive, this meant that students were happy with learning. Students think they can integrate the science process contained in the LKS based on local 
practicum materials. Discussion materials or questions available in the LKS are able to stimulate students to learn more actively and want to know more about their learning, students are more confident and more meaningful and able to reflect on their learning outcomes. This is what makes them more enthusiastic in participating in learning. Students feel that worksheets based on local practicum materials improve their learning evaluation because students are not only scored cognitively but also in a process. Overall the results of this questionnaire indicate that worksheets based on interesting local practicum materials give a positive response to students' cognitive learning outcomes and process skills. Through this positive learning, it is hoped that students will be able to explore more than just what they have obtained from the subject matter.

\section{Conclusion and Recommendations}

\subsection{Conclusion}

The production of worksheets based on locally developed practicum materials that refer to the feasible and effective scientific process steps (Scientific). The students' science process skills in implementation class 1 increased, namely the pretest score of 51.49 increased to 82.92 and N-Gain 0.35 in the moderate category. The effectiveness test (implementation class 2) shows that there is an increase in process skills with $n$ Gain in the high category of 0.75

\subsection{Recommendations}

The recommendations in this study are 1) The LKS model based on local practicum materials is an alternative that teachers can use to train elementary school students' science process skills 2) Science process skills can be integrated with the character values that the teacher wants to instill through scientific activities and 3) Further product development can be done by utilizing the potential of local wisdom, because the potential for local practicum materials in Central Kalimantan is still a lot to be used as practical materials and other lessons.

\section{References}

[1] Devi, K.P, Renny S dan Yayan. Pendekatan Keterampilan Proses Pada Pembelajaran. Jakarta : Depdiknas (2011)

[2] Juhji. Peningkatan Keterampilan Proses Sains siswa melalui Pendekatan Inkuiri Terbimbing. JPPI, Vol. 2, No. 1, Juni 2016, Hal 58-70. E-ISSN 2477-2038 (2016)

[3] Kemendikbud. Kerangka Dasar Kurikulum 2013. Kementerian Pendidikan dan kebudayaan Direktorat Jenderal Pendidikan Dasar. Jakarta (2013)

[4] Nuh. 2010. Keterampilan Proses Sains, diakses dari http://repository.ipi.edu/j-fis060940 pada tanggal 30 Maret 2019.

[5] Retnosari, G. 2015. Pengembangan LKS Berbasis Inkuiri Terbimbing pada Materi Suhu dan Perubahannya. http://digilib.unila.ac.id/10408 pada tanggal 13 Nopember 2019.

[6] Rezba, R.J, Sprague, C.S, Fiel, R.L, Funk HJ, Okey, J.R dan Jaus, H.H. Learning and Assesing Science Process Skill Third Edition. Iowa : Kendall/Hunt Publishing Company. (1999) 
[7] Susanto, A. Teori Belajar dan Pembelajaran di Sekolah Dasar .Jakarta.: Kencana Prenada Media Group (2014)

[8] Susilo, Abas \& Atun, Sri. Pengembangan LKS IPA untuk Meningkatkan Ketrampilan Proses Sains Dan Kemampuan Berpikir Kritis Siswa SMP. Jurnal Edukasi Matematika dan Sains. 5. 8. 10.25273/jems.v5i1.1781. (Diakses tanggal 13 Nopember 2019)

[9] Warianto. Keterampilan Proses Sains. Kencana Prenada Media Group. Jakarta. (2011) 